\section{Judges and Higher Education: A Troublesome Precedent}

\section{Alan L. Contreras}

Alan L. Contreras has been administrator of the Oregon Office of Degree Authorization, a unit of the Oregon Student Assistance Commission, since 1999. His views do not necessarily represent those of the commission. Address: ODA/OSAC, 1500 Valley River Drive, Eugene OR 97401. http://www.osac.state.or.us/oda/.E-mail: Alan.L.Contreras@state.or.us.

$\mathrm{T}$ The world of genuine education awoke to a rude surprise on 1 July 29, 2006, for on the previous day Mr. Justice Eady of the British High Court ruled that the Daily Mirror newspaper had libeled a celebrity hypnotist by saying (in articles in I997 and again in 2003) that his PhD from LaSalle University of Louisiana was bogus. The hypnotist, one Paul McKenna, who performs on television and works with many famous clients, had no other degrees at the time. The judge said that the newspaper had not shown that its statements about LaSalle were "substantially true."

This is nonsense. Seek in vain for LaSalle of Louisiana, unless you seek among the records of the Federal Bureau of Investigation, the US Postal Inspection Service, the courts of Louisiana, or the federal prison in Beaumont, Tex., where LaSalle's owner (who used various names) served time for running the fraudulent college from which McKenna acquired his degree.

Having read the entire opinion, I can say that Eady deserves an award for listening to such a peculiar case filled with halftruths, quarter-truths, and untruths and then writing an exceptionally clear, thoughtful opinion. That his conclusions are fundamentally mistaken on the question of whether LaSalle degrees equal the usual sense of the term involves the exceptional obscurity of American education law as much as it does Mr. McKenna's actions. The case also sets a very bad precedent for the international use of degrees.

\section{The Term "Bocus"}

Anyone interested in the actual history of LaSalle can read about it in Allen Ezell and John Bear's book Degree Mills (Prometheus, 2005). LaSalle, its history, its brethren, and its spawn are all detailed there. A similar account is available in the new, now ironically named publication Guide to Bogus Institutions and Documents (June, 2006) from the American Association of Collegiate Registrars and Admissions Officers.

McKenna argued successfully about not knowing of LaSalle's baseless accreditation, and the judge agreed that it was unreasonable to expect him to have known. That argument is doubtful but not outrageous, considering that Mr. McKenna is an uneducated person who had to go outside the
United Kingdom to acquire any degree. But the judge went on to say, as quoted by Michael Herman in the Times of London: "whatever one may think of the academic quality of his work, or of the degree granted by LaSalle, it would not be accurate to describe it as "bogus."

These words appear mild and even judicial in temperament, but consider what they mean in reality. A judge in one country declares that an entity in another country is a legitimate doctoral institution, although it is contrary to the universally understood status of the degree supplier in its home country. The misunderstanding comes about because the judge fails to realize that authority to issue degrees in the United States comes from states that may in fact have no meaningful standards for such programs - as was the case in Louisiana in the I99os and in Mississippi today. As the judge found, LaSalle was issuing degrees legally under the laws of Louisiana, but what the judge did not grasp was that the degrees issued did not represent academic learning. The term "bogus" as tossed around in this case did not refer to the legality of the institution; it referred to the nature of its product relative to the standard expectations of a college degree.

\section{An International Precedent?}

The McKenna case thus sets a strange precedent for who decides the international use of degrees. Until now, we could generally assume that each country gets to decide what is and is not a meaningful college degree within its own boundaries. The fact that LaSalle was briefly allowed to operate as a religious-exempt institution (i.e., exempt from oversight, on religious grounds) in Louisiana (a status acquired by building a church on its lawn) became irrelevant on the day that its owner was convicted of degree fraud, and of course its PhDs were risible from the beginning.

All degrees are by definition academic credentials. Doctoral degrees issued by LaSalle are invalid academic credentials.

I can say that Eady deserves an award for listening to such a peculiar case filled with half-truths, quarter-truths, and untruths and then writing an exceptionally clear, thoughtful opinion.

LaSalle never issued what anyone in American education would accept as genuine degrees. The hiring of LaSalle degree holders constitutes shoddy screening practices of employers, not degree acceptability.

Justice Eady's opinion assumes that any entity claiming to be a college is capable of issuing genuine doctoral degrees, provided that it can produce the barest mist of a holographic image of pillars around itself. I readily concede that he has the right to do that within the norms of British law, provided that he is making that decision about a British degree granter. In 
the McKenna case, he made that decision about a US degree grantor, which he should not have, and he got it wrong.

In paragraph 36 of the opinion, the judge wrote that whether a LaSalle degree is "scholarship worthy of academic recognition" is not the matter being litigated. The fact that the judge italicized the word "academic" only emphasizes the underlying problem: All PhDs are academic, and must be so to be genuine, and no such thing as a nonacademic PhD exists. In paragraph 6o, Eady repeats this odd view when he mentions the distinction between the academic value of the $\mathrm{PhD}$ and "its practical use." It is not difficult to get some practical use out of a bogus $\mathrm{PhD}$ - for a while. If that were the standard upon which issuance of PhDs were to be based, we would all be calling each other "Doctor."

Thus, Eady got it wrong, but the greater concern involves his determination about a foreign college contrary to how the home nation would treat such a college. I hope that other British judges do not make the same error and that this case remains not an anomaly but an utterly freakish event, as it is widely viewed in the education community. Does Great Britain really have nonacademic doctorates?

\section{Degrees Are Not Com modities}

Finally, it is important to compare this case with the recent cases involving fake schools in Liberia. In the St. Regis case, a US court was presented evidence that the college's approval in Liberia had been obtained through fraudulent means and bribery and that the approval was therefore invalid, as were the degrees. The court then ruled against St. Regis. Any nation should hold the right to decide whether degrees issued by a socalled college in a foreign country are substandard or fake and therefore unusable in the receiving nation, based on evidence supporting that view. Degrees cannot be imported like coal: degrees are not commodities and do not uniformly contain the same ingredients. All nations need the right to protect their citizens from fakes.

No nation has the right to compel acceptance of degrees issued by a fake school in another country, simply because someone thought it was a real school. In fact, Mr. Justice Eady has done the academic community a favor by saying that the Mirror newspaper had not shown that LaSalle was sufficiently bogus. This should wake up the British ministry in charge of postsecondary education, which will, I hope, establish a meaningful screening system for grossly substandard degrees issued by fly-by-night suppliers in other countries.

This article originally appeared in Inside Higher Education, August 3, 2006 (http://insidehighered.com/).

\section{Universities and Leaders: A Causal Link}

\section{AMANDA GOODALL}

Amanda Goodall is a doctoral researcher at Warwick Business School, University of Warwick, UK CV4 7AL. E-mail: amanda@amandagoodall .com. The full version of this article can be obtained from the author.

Cor a number of years, a question about university leader${ }_{\text {ship has circulated across many countries: should research }}$ universities be led by good scholars? Given the importance of academic research to the mission of universities this seems a logical inquiry. An alternative question, one that has been aired particularly in the United Kingdom, asks: is it more essential that university presidents are good managers? Search committees from Beijing to Budapest grapple with these issues.

New research is showing that a university led by a good scholar will improve its performance level. Likewise, universities led by weaker scholars will proceed to decline relative to the average level. Thus a causal link appears to exist between a leader's research ability and future university performance. The evidence for causality comes from the time frame and goes beyond a simple cross-section correlation.

In my earlier article, "The Leaders of the World's Top Ioo Universities" (IHE, no. 42, Winter 2006), I reported the strong correlation between the individual lifetime citations of a university president and the position of that university in a global ranking. In other words, the top universities are being led by better scholars. A follow-up study of mine focused on deans of business schools and found a strong correlation between the position of a business school in the Financial Times Global MBA ranking and the lifetime citations of its dean.

\section{A Longitudinal Study}

Recent work on the performance of 55 UK research universities over a nine-year period focuses on the issue of causality. By drawing upon longitudinal data, the study attempts to go beyond cross-section patterns. It uses regression analysis, with university performance as the dependent variable, and the lifetime citations of presidents as the key independent variable. The study also inputs controls for the university income, the president's age, and the academic discipline of presidents.

An established measure of performance is used, one that has existed in the United Kingdom since I986-the so-called research assessment exercise (RAE). Unlike league tables, RAE is based on a more objective system of peer review; it provides quality ratings for research across all disciplines. The data in the study come from 55 universities-namely, institutions that 